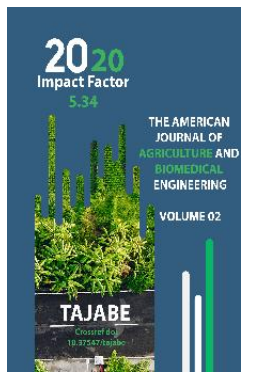

Journal Website: http://usajournalshub.c om/index,php/tajabe

Copyright: Original content from this work may be used under the terms of the creative commons attributes 4.0 licence.

\section{Biometric Indicators Of New Soybean Varieties In The Conditions Of Meadow-Swampy Soils Of Tashkent Region}

\author{
Sattarov Masud Akhtamovich \\ Phd, Senior Scientific Researcher, Rice Research Institute, Uzbekistan.
}

Idrisov Husanzhan Abdujabborovich

Junior Research Fellows, Rice Research Institute, Uzbekistan.

\title{
ABSTRACT
}

This article analyzes the data on biometric indicators of new promising varieties of soybean "Tashkent", "Sevinch" and "Madad". According to the results of the study, the yield was 3.8-3.8 $\mathrm{t} / \mathrm{ha}$ in "Tashkent" variety, 3.8-3.3 t/ ha in "Sevinch" variety and 3.6-3.9 t/ha in "Madad" variety.

\section{KEYWORDS}

Soybean, seedling field, sample, variety, "Sevinch”, “Madad”, “Tashkent”, protein, branch, legume, yield.

\section{INTRODUCTION}

In the Action Strategy for the five priority areas of development of the Republic of Uzbekistan for 2017-2021, approved by the Decree of the President of the Republic of Uzbekistan dated February 7, 2017, the implementation of measures to further develop and liberalize the economy remains the most important way to improve the welfare of our people. The Resolution of the President of the Republic of Uzbekistan No.PD-2832 of March 14, 2017 and the Resolution of the President of the Republic of Uzbekistan No.PD-3144 of July 24, 2017 became the basis for the organization and development of soybean in the Republic. Increase export potential, further optimize arable land, increase the share of food crops, deep processing, storage, transportation and sale of agricultural products, development of agrochemical, financial and other modern infrastructure systems, increase crop yields and product quality as well as the creation of new selection varieties resistant to biotic and abiotic factors, and set a task for experts in the field. 
At present, the country pays great attention to grain, legumes and oilseeds and expands their arable lands. Great opportunities have opened up for the development of agriculture and the efficient use of land. One of the most pressing issues today is the protein issue, which is to meet humanity's demand for protein. The soybean crop from legumes is of great importance in solving this problem. Soybeans contain $40-55 \%$ protein and $20-25 \%$ fat

About $35 \%$ of the vegetable oil produced worldwide is derived from soybeans. Soybeans and isolates are the best raw materials in the food industry, as well as protein-rich nutritious feed in livestock, poultry and fisheries. It is estimated that there are 107 million hectares field of soybean in the world today. Cultivated on an area of more than a hectare. Of this, about $36.3 \mathrm{mln}$. hectares in the United States, 33.7 million. hectares to Brazil. Soybean grain yields are also higher than many other crops. More than 400 different products are obtained from the seeds of this plant. In addition to butter, soybean milk, soybean protein, soybean isolation and other products are widely used in the world food industry today. In the food industry, defatted soybean flour is used to make bread, bakery and other confectionery products. Isolation of soybean is used in the technical fields of textiles, textiles, paper and industry. Soybean oil is widely used in the manufacture of soap and lacquer paints. In the world, soybean production in 2014/2015 amounted to 118.14 million tons. 317.25 million hectares were planted. tons of soybeans were harvested. The highest yields belong to U.S. farmers, with an average yield of $3.21 \mathrm{t} / \mathrm{ha}$, while the lowest yields are in India, averaging $0.9 \mathrm{t} / \mathrm{ha}$. obtained from. Worldwide soybean production in 2017/2018 was 146 million tons, which is $5 \mathrm{mln}$.tons. In the U.S., Soybean areas are expanding further as farmers earn more from soybean than from corn.

In agriculture around the world, the area under soybeans and legumes, which are legumes, is expanding day by day due to the increase in the variety of high-value food products from grain and the high coverage of processing.

In recent years, special attention has been paid to the placement and cultivation of nontraditional agricultural crops in the country. In particular, in 2017, for the first time in the country, soybeans were planted on more than 12,000 hectares, 14,000 tons of soybeans were grown, and more than 2,000 tons of soybean oil and 10,000 tons of high-nutrient soybean meal were delivered to poultry farms.

\section{THE PURPOSE AND OBJECTIVES OF THE EXPERIMENT}

To provide our people with food, solve protein deficiencies, increase oil production, provide livestock with nutritious food and increase soil fertility, soybean and mungbean crops, highyielding, grain-rich in protein and fat, resistant to diseases and pests, and a variety of soils. The creation of new varieties for primary and secondary crops, adapted to climatic conditions.

Much work has been done at the Rice Research Institute to create new varieties of soybeans and introduce them into production. This works is currently conducting; scientific works is underway to create new varieties.

\section{LOCATION OF THE EXPERIMENT AND SOIL- CLIMATIC CONDITIONS}

Scientific research was conducted in the field of 12th map on 2nd edge (0.50) of the experimental field of the Rice Research Institute. 
The experimental field is located in the southeastern part of the Tashkent region, $15 \mathrm{~km}$ distance from Tashkent, on the left bank of the Chirchik River, on the Greenwich scale at 69018 'Eastern longitude and 41020' North latitude.

The soil layer in the experimental area is meadow-swampy, muddy, sandy soil. It is known that sierozem soils are less stratified and are characterized by a lack of humus, which is also evident from the peculiar color that occurs in meadow swampy soils.

The driving layer of the experimental farm of the Rice Research Institute is $0-30$ and $0-40$ $\mathrm{cm}$, below the driving layer is a layer of gel 30$40 \mathrm{~cm}$ thick, at a depth of $60-70 \mathrm{~cm}$ there is a layer of sand and small stones.

Experimental style. Soybean selection was carried out on the basis of generally developed methods for the creation of new varieties of agricultural crops and the recommendations developed by the Rice
Research Institute, as well as field experimental methods.

Experimental results. A result of the research Experimental work was carried out in the experimental fields of the Rice Research Institute. In 2018-2019, the soybean variety "Tashkent" was tested and the following biometric indicators were identified. The growth period of the Tashkent variety was 120 days in 2018 and 119 days in 2019. The plant height was 150-155 cm over the years, with a difference of $5 \mathrm{~cm}$. It was observed that the number of seedlings was 25 and 27 seeds per 1 running meter. The location of the low pods was $14 \mathrm{~cm}$ in 2018 and $16 \mathrm{~cm}$ in 2019. The number of branches per year was 2.0 and 3.0, while the number of pods per plant was 85 in 2018 and 100 in 2019. The weight of 1000 grains was 171.4-173.0 g. The yield of this variety in Tashkent was $3.8 \mathrm{t} / \mathrm{ha}$ in 2018 and $3.8 \mathrm{t} / \mathrm{ha}$ in 2019. Detailed information on all biometric indicators is given in the table below. 
The American Journal of Agriculture And Boimedical Engineering (ISSN - 2689-1018)

Published: August 25, 2020 | Pages: 61-66

Doi: https://doi.org/10.37547/tajabe/Volume02Issue08-07

\section{Table 1}

Biometric indicators of "Tashkent" variety

\begin{tabular}{|c|c|c|c|}
\hline \multirow{2}{*}{ № } & Indicators & \multicolumn{2}{|c|}{ Years } \\
\cline { 2 - 4 } & & $\mathbf{2 0 1 8}$ & $\mathbf{2 0 1 9}$ \\
\hline 1 & Growth period, day & 120 & 119 \\
\hline 2 & Plant height, cm & 150 & 155 \\
\hline 3 & Number of plants, pieces/m ${ }^{2}$ & 25 & 27 \\
\hline 4 & Lower bean placement, cm & 14 & 16 \\
\hline 5 & Number of branches, pieces & 2,0 & 3,0 \\
\hline 6 & The number of pods per plant & 85 & 100 \\
\hline 7 & 1000 grain weight, gr & 171.4 & 173.0 \\
\hline 8 & Productivity, t/ha & 3.3 & 3.3 \\
\hline
\end{tabular}

In our research, as well as in 2018-2019, the soybean variety "Sevinch" was tested and the following biometric indicators were identified. The growth period of the Sevinch variety was 119 days in 2019, compared to 118 days in 2018. The plant height was $155-144 \mathrm{~cm}$ over the years, with a difference of $11 \mathrm{~cm}$. It was observed that the number of seedlings was 21 and 24 pieces per 1 running meter. The location of the first pods was $14 \mathrm{~cm}$ in 2018 and $16 \mathrm{~cm}$ in 2019. The number of branches was 2.0 and 3.0 per year, respectively, and the number of pods per plant was 103 in 2018 and 110 in 2019. The weight of 1000 grains was 182.0-184.8 $\mathrm{g}$ over the years. It was also observed that the yield of the Sevinch variety was $3.8 \mathrm{t} / \mathrm{ha}$ in 2018 and $3.3 \mathrm{t} / \mathrm{ha}$ in 2019. Detailed data are given in the table below. 
The American Journal of Agriculture And Boimedical Engineering (ISSN - 2689-1018)

Published: August 25, 2020 | Pages: 61-66

Doi: https://doi.org/10.37547/tajabe/Volume02Issue08-07

Table 2

Biometric indicators of "Sevinch" variety of soybean

\begin{tabular}{|c|c|c|c|}
\hline \multirow{2}{*}{ № } & \multirow{2}{*}{ Indicators } & \multicolumn{2}{|c|}{ Years } \\
\cline { 3 - 4 } & & $\mathbf{2 0 1 8}$ & $\mathbf{2 0 1 9}$ \\
\hline $\mathbf{1}$ & Growth period, day & 118 & 119 \\
\hline $\mathbf{2}$ & Plant height, cm & 155 & 144 \\
\hline $\mathbf{3}$ & Number of plants, pieces / m ${ }^{2}$ & 21 & 24 \\
\hline $\mathbf{4}$ & Lower bean placement, cm & 14 & 16 \\
\hline $\mathbf{5}$ & Number of branches, pieces & 2 & 3 \\
\hline $\mathbf{6}$ & The number of pods per plant & 103 & 184.8 \\
\hline $\mathbf{7}$ & 1000 grain weight, gr & 182.0 & 3.3 \\
\hline $\mathbf{8}$ & Productivity, t/ha & 3.8 & \\
\hline
\end{tabular}

In our research work, The "Madad" variety of soybean was tested in 2013-2014 and the following biometric indicators were determined. The growing period of the "Madad" variety was 134 days in 2018 and 137 days in 2019. There was a difference of 3 days over the years. The plant was $145-152 \mathrm{~cm}$ height, with a difference of $7 \mathrm{~cm}$. It was observed that the number of seedlings was 22 and 24 pieces per 1 running meter. The location of the lower pod was $18 \mathrm{~cm}$ in 2018 and $17 \mathrm{~cm}$ in 2019. The number of branches was 3.0 per year, and there was no difference. The number of pods per plant was 93 in 2018, and in 2019 there were 16 pods more than in the previous year, i.e 109 pods were formed. The grain weight of 1000 grains was 175.0$173.4 \mathrm{~g}$, and in 2019 the grain weight was found to have decreased by $1.6 \mathrm{~g}$. There was no difference between the yield of this Madad variety, which was $3.4 \mathrm{t} / \mathrm{ha}$ in 2018 and $3.4 \mathrm{t} / \mathrm{ha}$ in 2019. Details are given in the table below. 
The American Journal of Agriculture And Boimedical Engineering (ISSN - 2689-1018)

Published: August 25, 2020 | Pages: 61-66

Doi: https://doi.org/10.37547/tajabe/Volume02Issue08-07

Table 3

Biometric indicators of "Madad" variety of soybean

\begin{tabular}{|c|c|c|c|}
\hline \multirow{2}{*}{ No } & \multirow{2}{*}{ Indicators } & \multicolumn{2}{|c|}{ Years } \\
\cline { 3 - 4 } & & $\mathbf{2 0 1 8}$ & $\mathbf{2 0 1 9}$ \\
\hline $\mathbf{1}$ & Growth period, day & 134 & 137 \\
\hline $\mathbf{2}$ & Plant height, cm & 145 & 152 \\
\hline $\mathbf{3}$ & Number of plants, pieces / $\mathrm{m}^{2}$ & 22 & 24 \\
\hline $\mathbf{4}$ & Lower bean placement, cm & 18 & 17 \\
\hline $\mathbf{5}$ & Number of branches, pieces & 3 & 3 \\
\hline $\mathbf{6}$ & The number of pods per plant & 93 & 109 \\
\hline $\mathbf{7}$ & 1000 grain weight, gr & 175.0 & 3.6 \\
\hline $\mathbf{8}$ & Productivity, t/ha & 3.9 & \\
\hline
\end{tabular}

\section{CONCLUSIONS}

According to the results of the study, all biometric indicators of the newly created soybean varieties "Tashkent", "Sevinch" and "Madad" were studied, and these prospective varieties were handed over to the Center for Testing Varieties of Agricultural Crops.

\section{REFERENCES}

1. Resolution of the President of the Republic of Uzbekistan Sh.M.Mirziyoev dated March 14, 2017 No.PP-2832 "On measures to increase the sowing of soybeans and soybeans breeding in the country in 2017-2021."
2. Resolution of the President of the Republic of Uzbekistan Sh.M.Mirziyoev dated July 24, 2017 on amendments and additions to the Resolution No.PD-3144 No.PD-2832.

3. Atabaeva H.N.- Soya - T. National Encyclopedia, 2004, p.95

4. Atabaeva .H.N., Israilov I.A., Umarova N.S. Soybean morphology and biological cultivation technology. 2011, 11 pages.

5. Dospexov B.A. Methodology of field experiments. $-\mathrm{M}$ :., Kolos, $1985 \mathrm{~g}$. 